This paper is accepted for publication in Marine Pollution Bulletin (July 2010). Therefore, only an extended abstract and a summary table is given as contribution for the conference DVD.

\title{
The use of benthic indicators in Europe: from the Water Framework Directive to the Marine Strategy Framework Directive
}

Van Hoey ${ }^{1, *}$, Gert; Borja ${ }^{2}$, Angel; Birchenough ${ }^{3}$, Silvana; Degraer ${ }^{4}$, Steven; Fleischer ${ }^{5}$, Dirk; Kerckhof ${ }^{4}$, Francis; Magni ${ }^{6,7}$ Paolo; Buhl-Mortensen ${ }^{8}$, Lene; Muxika ${ }^{2}$, Iñigo; Reiss ${ }^{9}$, Henning; Schröder ${ }^{10}$, Alexander; Zettler ${ }^{11}$, Michael L.

Affiliation:

${ }^{1}$ ILVO-fishery: Biological Environmental Research Division; Ankerstraat 1; 8410 Ostend (Belgium); T. +32(0)59-569847; F. +32(0)59-330629

${ }^{2}$ AZTI-Tecnalia; Marine Research Division; Herrera Kaia, Portualdea s/n; 20110 Pasaia (Spain)

${ }^{3}$ Cefas, The Centre for Environment, Fisheries and Aquaculture Science, Lowestoft Laboratory, Pakefield Road, Lowestoft, Suffolk, NR 33 OHT, (United Kingdom).

${ }^{4}$ Royal Belgian Institute of Natural Sciences, Management Unit of the North Sea Mathematical Models, Marine Ecosystem Management Section, Gulledelle 100, 1200 Brussel (Belgium)

${ }^{5}$ Leibniz Institute for Marine Sciences IFM-GEOMAR, Wischhofstr. 1-3, 24148 Kiel (Germany)

${ }^{6}$ CNR-IAMC, Consiglio Nazionale delle Ricerche, Istituto per l'Ambiente Marino Costiero, Loc. Sa Mardini, Torregrande, 09072 Oristano (Italy)

7 CNR-ISMAR, Consiglio Nazionale delle Ricerche, Istituto di Scienze Marine, Riva Sette Martiri 1364/a, 30122 Venezia (Italy)

${ }^{8}$ Institute of Marine Research, PB 1870 Nordnes,N-5817 Bergen (Norway)

${ }^{9}$ Senckenberg Institute, Dept. of Marine Science, Suedstrand 40, 26382 Wilhelmshaven (Germany)

10 Alfred Wegener Institute for Polar and Marine Research, Am Handelshafen 12, 27570

Bremerhaven (Germany)

${ }^{11}$ Leibniz Institute for Baltic Sea Research Warnemünde, Seestr. 15, 18119 Rostock (Germany)

*Corresponding author: Gert.vanhoey@ilvo.vlaanderen.be

\section{ABSTRACT}

The European Water Framework Directive (WFD; 2000/60/EG) and the European Marine Strategy Framework Directive (MSFD; 2008/56/EC) were umbrella legislations for fresh and marine waters. It is a challenge for the scientific community to translate the principles of these directives into realistic and accurate approaches. Both directives have the same concept, comparing the current state of an area with that which would be expected under minimal or sustainable human use of that area and in case of degradation, intervening to bring it back to the desired good status. However, each directive used specific principles to fill it in. For the WFD, this was executed during the last decade, and many results of it were already published. This process delivered valuable knowledge on which the implementation of the MSFD can be founded.

Therefore, the ICES Benthos Ecology Working Group aimed to stress and discuss some issues, with focus on benthic macro-invertebrates, related to the fulfillment of the principles of both directives. This through the description of (1) how the principles are theoretically filled in by both directives 
(realization), (2) what the challenges or lessons learnt are, mainly from WFD point of view, and (3) what the way forward is, especially in the light of the implementation of the MSFD (Table 1). First we considered the use of the 'ecosystem approach' principle in both directives. A second topic addressed, is in relation to the definition of the good ecological status (GES; WFD) and the good environmental status (GEnS; MSFD), and handles on the development of benthic indicators for classification, definition of 'pristine' or sustainable conditions and the importance of relating ecological measurements to pressures. In this case, we discussed the problems related to detecting different anthropogenic impact types, distinguishing between anthropogenic versus natural changes by indicators and how to evaluate the pressure non-indigenous or alien species. The third topic addressed is on the monitoring programs (effort and quality), which have to provide sufficient information to allow a confident assessment of GES and GEnS. For each principle, the BEWG formulated some advices on how to proceed in the future (Table 1).

We conclude that the implementation of the WFD has led to dedicated scientific research in support of ecological or environmental assessments, with the development of many indicators, and discussions concerning the fulfillment of the principles of the directive. This review promoted a good understanding of the strengths and weaknesses of the proposed principles in the WFD, which were widely discussed in the literature. Especially, concerning benthic invertebrates, the literature knowledge is extensive resulting from the widespread tradition in benthic research in relation to environmental assessment. The MSFD defined similar goals as the WFD, but some principles are distinctly different, as identified in this contribution. This was in the first instance to avoid a need to develop new methods.

Due to the spatial extent of the marine areas and the ecosystem complexity, the use of single indicators for a wide area is difficult, and for some indicators, many effort is required to make a confident assessment. The implication of well founded sampling strategies related to habitat types as well as spatially definable pressure gradients is an indispensable prerequisite for a reliable status assessment and for an evaluation of the effectiveness of management activities. Indicators deliver evidence based information, but there are shortcomings and precaution is always required concerning their use in ecological or environmental assessment. Therefore, experts have to be involved in all steps of ecological or environmental assessments at the various levels of administration (regional to EU) to ensure the quality.

All proposed approaches have advantages and disadvantages and the ultimate approach does not exist. Discussion and testing of approaches lead to further insights and improvements in their selection for evaluating the ecological or environmental status. Every approach is applicable ideally in certain regions or for certain purposes, but does not cover all problems. However, care has to be taken to ensure comparable assessment strategies across the regions, to allow a region-wide status assessment on the same basis. The degree of applicability of approaches depends on the complexity of the method and its requirements. The WFD has initiated and accelerated the scientific research on this topic, and the MSFD can profit from it. Consequently, a good communication is required between the people implementing the MSFD and those implementing the WFD. 
Keywords: Water Framework Directive, Marine Strategy Framework Directive, Macro-invertebrates, indicators, ecosystem approach, monitoring 


\begin{tabular}{|c|c|c|c|}
\hline Principles & & Water Framework Directive & Marine Strategy Framework Directive \\
\hline \multirow{3}{*}{$\begin{array}{l}\text { Use of the } \\
\text { Ecosystem } \\
\text { approach }\end{array}$} & Realization & $\begin{array}{l}\text { Biological quality elements with supporting chemical, } \\
\text { physico-chemical and hydromorphological variables }\end{array}$ & $\begin{array}{l}\text { Eleven descriptors, with several indicators covering ecological, } \\
\text { physical, chemical and anthropogenic components of the } \\
\text { ecosystem }\end{array}$ \\
\hline & Challenge & $\begin{array}{l}\text { Integration of the elements based on } \\
\text { 'one out - all out principle', which is not always appropriate }\end{array}$ & $\begin{array}{l}\text { Selection of the appropriate indicators and the integration of the } \\
\text { several indicators per descriptor }\end{array}$ \\
\hline & Way to go & \multicolumn{2}{|c|}{$\begin{array}{l}\text { Scientific selection of elements/indicators in relation to their sensitivity, robustness and confidence. } \\
\text { Integration of indicators based on a decision tree process, with a clear visibility of the integration acts at indicator and descriptor } \\
\text { level. }\end{array}$} \\
\hline \multirow{3}{*}{ Benthic Indicators } & Realization & $\begin{array}{l}\text { - National approaches, which require } \\
\text { intercalibration } \\
\text { - Multi-metric benthic indicators }\end{array}$ & $\begin{array}{l}\text { - } \quad \text { Regional approach, with common indicators } \\
\text { - Mainly univariate indicators per descriptor }\end{array}$ \\
\hline & Challenge & Comparability of the national approaches & $\begin{array}{l}\text { - } \quad \text { No comparability tests on indicator level needed, but still on } \\
\text { other aspects of the Directive (e.g. GEnS thresholds) } \\
\text { - } \quad \text { Sensitivity of single univariate benthic indicators less clear! }\end{array}$ \\
\hline & Way to go & $\begin{array}{l}\text { - The selection of appropriate indicators, with comple } \\
\text { - Integration of single univariate indicators required t }\end{array}$ & $\begin{array}{l}\text { mentary properties and related to the Directive objectives. } \\
\text { detect the complex response of benthos }\end{array}$ \\
\hline \multirow{3}{*}{$\begin{array}{l}\text { From pristine } \\
\text { conditions to } \\
\text { sustainably } \\
\text { functioning } \\
\text { ecosystems }\end{array}$} & Realization & $\begin{array}{l}\text { Reference = 'undisturbed (pristine) condition', to be } \\
\text { determined based on reference sites or benchmarking }\end{array}$ & $\begin{array}{l}\text { Reference = 'sustainable functioning ecosystems', but no } \\
\text { methodology for determining thresholds for GEnS }\end{array}$ \\
\hline & Challenge & $\begin{array}{l}\text { - } \quad \text { No benthic reference sites, poor historical data } \\
\text { - Expert judgment good first step, but needs } \\
\text { funding }\end{array}$ & $\begin{array}{l}\text { - What is good or sustainable? } \\
\text { - No single GEnS thresholds for any indicator will be } \\
\text { appropriate within a region }\end{array}$ \\
\hline & Way to go & $\begin{array}{l}\text { - The use of clear stressor-response data } \\
\text { - } \quad \text { Defining the 'naturalness' of the system }\end{array}$ & \\
\hline \multirow{2}{*}{$\begin{array}{l}\text { Anthropogenic } \\
\text { pressure types }\end{array}$} & Realization & Indices have to prove their pressure type dependency & $\begin{array}{l}\text { Indicators have to be selected based on pressure type (most } \\
\text { appropriate, measurable) }\end{array}$ \\
\hline & Challenge & $\begin{array}{ll}\text { - } & \text { Multi-pressure environments } \\
\text { - } & \text { Large scale pressures } \\
\text { - } & \text { No impact free areas }\end{array}$ & \\
\hline
\end{tabular}




\begin{tabular}{|c|c|c|c|}
\hline & Way to go & \multicolumn{2}{|c|}{$\begin{array}{l}\text { - } \quad \text { Marine Protected Areas (MPA's) } \\
\text { - } \quad \text { Accurate and detailed quantification of the pressure types in the marine systems }\end{array}$} \\
\hline \multirow{3}{*}{$\begin{array}{l}\text { Natural versus } \\
\text { anthropogenic } \\
\text { response }\end{array}$} & Realization & \multicolumn{2}{|l|}{ Indicators not or less sensitive to natural variability } \\
\hline & Challenge & $\begin{array}{l}\text { Currently less investigations regarding sensitivity of } \\
\text { indicators to natural variability and scoping the natural } \\
\text { variability in defining reference conditions }\end{array}$ & Availability of detailed data on large temporal and spatial scale \\
\hline & Way to go & \multicolumn{2}{|c|}{$\begin{array}{l}\text { - Integration of all available temporal and spatial data information } \\
\text { - } \quad \text { The use of spatially well designed monitoring systems }\end{array}$} \\
\hline \multirow{3}{*}{$\begin{array}{l}\text { Alien species or } \\
\text { non-indigenous } \\
\text { species }\end{array}$} & Realization & Alien species were considered as a pressure & Non-indigenous species is a descriptor \\
\hline & Challenge & $\begin{array}{l}\text { - } \quad \text { May not be present at high status. } \\
\text { - } \quad \text { Measures to remove or reduce the impact are } \\
\text { scarce }\end{array}$ & Measures to remove or reduce the impact are scarce \\
\hline & Way to go & \multicolumn{2}{|c|}{$\begin{array}{l}\text { - Research has to focus on the effect of alien species (function, niche) on the ecosystem } \\
\text { - } \quad \text { Prevention of further invasions by early warning systems (precautionary principle) }\end{array}$} \\
\hline \multirow{3}{*}{$\begin{array}{l}\text { Monitoring } \\
\text { requirements for } \\
\text { environmental } \\
\text { assessment }\end{array}$} & Realization & Monitoring programs on national level & $\begin{array}{l}\text { National monitoring programs to be integrated on regional sea or } \\
\text { sub-sea level }\end{array}$ \\
\hline & Challenge & \multicolumn{2}{|c|}{$\begin{array}{l}\text { - Influence of sampling strategy type on assessment results } \\
\text { - } \quad \text { Diversity of national approaches in sampling strategy }\end{array}$} \\
\hline & Way to go & \multicolumn{2}{|c|}{$\begin{array}{l}\text { - Use of the habitat approach (stratified sampling strategy) in benthos monitoring } \\
\text { - Incorporation of statistical power, effect size and variance determination in determining number of samples } \\
\text { - Setting of an adequate time scaling of the monitoring in relation to the indicator type } \\
\text { - Use of standard benthic quality assurance guidelines } \\
\text { - Adaptation of national monitoring programs towards cost-effective, integrative strategies } \\
\text { - A switch from 'station oriented monitoring' towards a 'basin or system oriented monitoring' }\end{array}$} \\
\hline
\end{tabular}

Table 1. Summary table of how some key principles of the Water Framework Directive and Marine Strategy Framework Directive were filled in, the associated challenges and the way forward. Note: GEnS: Good Environmental Status. 